\title{
HUBUNGAN TEKANAN PANAS DENGAN DENYUT NADI PEKERJA PADA AREA KERJA BRF DI PT X
}

\author{
CORRELATION BETWEEN HEAT PRESSURE AND PULSE WORKERS \\ AT WORK AREA BRF IN PT. X
}

\author{
Rieke Revina Rahadian \\ Departemen Keselamatan dan Kesehatan Kerja FKM UNAIR \\ Fakultas Kesehatan Masyarakat Universitas Airlangga \\ Alamat Korespondensi: \\ Rieke Revina Rahadian \\ E-mail: riekerahadian@gmail.com
}

\begin{abstract}
The increase in pulse on workers can occur due to heat pressure in the work environment combine with the physical workload received by workers. This research was conducted to identification the relationship between heat pressure and pulse on workers in the area of BRF $P T X$.

The research was an analytic observational with cross sectional design. The populations were 25 workers, and all of them were used as the samples, using total sampling technique. Bivariate analysis with Pearson correlation statistic test used to find out the correlation between heat stress and worker's pulse.

The measurement of heat stress was conducted by using digital QuesTemp. It were founded that BRF work area has an exceed heat stress compared with Threshold Limit Value (TLV) the results was $34,6^{\circ} C$. The measurement of worker's pulse was conducted by using palpation method with stopwatch. It were found that before and after work, 3 workers had not increase pulse and 22 workers had increase pulse. The results of statistic test showed that there was significant positive correlation between heat stress and worker's pulse in the workers at BRF $P T X$ with the value of $r=0,507$ it means the correlation about two variables was strong.

It is recommended that the workers drink plain water as frequently as possible in order to return the lost of body liquid during working. Safety talk to enrich the knowledge workers on how to work in a heat environment. Using the uniform which consists of the materials that are not produce heat is quite recommended.
\end{abstract}

Keywords: Heat pressure, pulse, workers, BRF 


\begin{abstract}
ABSTRAK
Peningkatan denyut nadi pekerja terjadi karena tekanan panas yang ada di lingkungan kerja dan beban kerja fisik yang diterima oleh pekerja.Penelitian ini bertujuan untuk mengidentifikasi hubungan antara tekanan panas dan denyut nadi pada pekerja area BRF di PT X.

Penelitian ini adalah penelitian observasional analitik dengan desain studi cross-sectional. Populasi berjumlah 25 orang pekerja dan semua pekerja digunakan sebagai sampel dengan menggunakan teknik total sampling. Analisis bivariat dilakukan dengan menggunakan uji statistik korelasi Pearson untuk mengetahui seberapa kuat hubungan antara tekanan panas dengan denyut nadi pekerja.

Pengukuran tekanan panas dilakukan dengan menggunakan alat ukur digital QuesTemp.Hasil pengukuran ditemukan bahwa tekanan panas di area kerja BRF telah melebihi NAB yang diperkenankan, yaitu sebesar $34,6^{\circ} \mathrm{C}$.Pengukuran denyut nadi pekerja dilakukan dengan menggunakan metode palpasi (raba) dengan bantuan alat pengukur waktu (stopwatch). Dari hasil pengukuran sebelum dan sesudah bekerja, didapatkan 3 orang pekerja tidak mengalami peningkatan denyut nadi atau denyut nadinya tetap, dan sebanyak 22 orang pekerja mengalami peningkatan denyut nadi. Hasil dari uji statistik menunjukkan bahwa terdapat hubungan signifikan yang positif antara tekanan panas dan denyut nadi pekerja pada area kerja BRF di PT $\mathrm{X}$ dengan nilai $r=0,507$ yang menunjukka bahwa hubungan dua variabel tersebut kuat.

Disarankan kepada pekerja untuk meningkatkan konsumsi air minum sesering mungkin secara berkala untuk mengembalikan hilangnya cairan tubuh pada saat bekerja.Safety talkjuga perlu dilakukan untuk menambah pengetahuan pekerja tentang bagaimana caranya bekerja di lingkungan kerja panas. Selain itu, pekerja disarankan untuk menggunakan pakaian kerja berbahan yang dapat mengurangi rasa panas ditubuh.
\end{abstract}

Kata Kunci: Tekanan panas, denyut nadi, pekerja, BRF

\section{PENDAHULUAN}

Tempat kerja adalah tiap ruangan atau lapangan, terbuka, tertutup, bergerak ataupun tetap dimana tenaga kerja bekerja, atau yang sering di masuki tenaga kerja untuk keperluan suatu usaha dimana terdapat sumber-sumber bahaya (UU No. 1/ 1970 tentang Keselamatan dan Kesehatan Kerja). Sumber bahaya yang ditemukan di tempat kerja sangat beragam, salah satunya adalah kondisi fisik berupa iklim kerja panas. Kondisi ini hampir pasti ditemui di industri di Indonesia, seperti industri besi dan pengecoran logam baja, batu dan keramik, konstruksi, pembuatan produk berbahan dasar karet, pertambangan, kaca dan gelas, tekstil, dll. Namun sangat disayangkan hingga saat ini masih belum terlihat upaya maksimal untuk mengatasi hal tersebut (Vanani, 2010).

Negara Indonesia merupakan negara tropis dengan ciri utamanya adalah suhu dan kelembaban udara yang tinggi, kondisi awal seperti ini seharusnya sudah menjadi perhatian karena iklim kerja yang panas dapat mempengaruhi kondisi pekerja dan iklim kerja panas merupakan beban bagi tubuh ditambah lagi apabila pekerja harus mengerjakan pekerjaan-pekerjaan fisik yang berat yang dapat memperburuk kondisi kesehatan dan stamina pekerja (Vanani, 2010).

Menurut Suma'mur (2014) menyatakan bahwa suhu nyaman bagi orang Indonesia untuk bekerja berkisar antara $24-26^{\circ} \mathrm{C}$ dengan kelembapan $35 \%$ $60 \%$. Lebih dari itu, pekerja merasa tidak nyaman dalam bekerja. Terpajan oleh temperatur yang tinggi selama bekerja dalam ruangan dengan lingkungan panas atau bekerja di ruang terbuka dengan cuaca yang panas, merupakan suatu keadaan yang sangat berpotensi menimbulkan bahaya. Pajanan panas yang terdapat di tempat kerja, sewaktu-waktu dapat menimbulkan penyakit akibat kerja. Bila hal ini tidak dikendalikan maka akan menyebabkan menurunnya produktifitas pekerja yang berdampak langsung pada produktifitas perusahaan serta dapat menimbulkan peningkatan kecelakaan kerja. (Gullickson dalam Siswantiningsih, 2010). 
Respon-respon fisiologis akan nampak jelas terhadap pekerja dengan iklim kerja panas tersebut, seperti peningkatan tekanan darah dan denyut nadi. Hasil penelitian Aperos, et al. (2015) menyatakan bahwa terdapat hubungan yangyang signifikan antara tekanan panas dan denyut nadi pada pekerja di PT Perkebunan Nusantara IV Kebun Bah Butong tahun 2015 yang berpengaruh terhadap tingkat kenyamanan pekerja dan gangguan kesehatan. Adapun penyebabnya yaitu karena hilangnya cairan dari tubuh oleh penguapan keringat sebagai akibat dari iklim tempat kerja yang tinggi dan lembab. (Suma'mur, 2014).

Selain respon tekanan darah dan denyut nadi, sistem termoregulator di otak (hypothalamus) akan merespon dengan beberapa mekanisme kontrol seperti konduksi, konveksi, radiasi, dan evaporasi dengan tujuan untuk mempertahankan suhu tubuh sekitar $36^{\circ} \mathrm{C}-37^{\circ} \mathrm{C}$. Namun apabila tekanan dibiarkan terus-menerus akan menyebabkan kelelahan (fatigue) dan akan menyebabkan mekanisme kontrol ini tidak lagi bekerja yang pada akhirnya akan menyebabkan timbulnya efek heat stress (Imanuddin, 2012).

Tekanan panas (heat stress) pada suatu area kerja dipengaruhi oleh cuaca lingkungan kerja, panas metabolisme yang dihasilkan dari aktivitas fisik pekerja, serta dipengaruhi karakteristik pekerja seperti faktor umur, masa kerja, indeks masa tubuh, dan aklimatisasi. (NIOSH dalam Imanuddin, 2012). Panas ditempat kerja sebagai sebuah tekanan fisik dapat mengakibatkan perubahan fisiologis tubuh. Pemaparan panas secara terus menerus dapat mengakibatkan timbulnya heat strain, yaitu serangkaian respon fisik yang timbul akibat adanya tekanan panas, antara lain adalah banyaknya keringat yang dihasilkan, banyaknya keringat yang menguap, perubahan denyut nadi dan suhu tubuh. Selain itu, perubahan denyut nadi juga dapat mempengaruhi perubahan tekanan darah yang berdampak pada performansi kerja. Peningkatan denyut nadi dan tekanan darah membuat kerja jantung juga meningkat. Pekerja menjadi mudah lelah, tidak fokus dalam bekerja dan berisiko mengalami kecelakaan kerja maupun penyakit akibat kerja. (OSHA dalam Imanuddin, 2012).

Hasil penelitian terdahulu pada tahun 2010 mengenai pengaruh iklim kerja terhadap denyut nadi dan suhu tubuh pada tenaga kerja di PT. Barata Indonesia (Persero) Gresik Divisi pengecoran dengan ISBB $44,52^{\circ} \mathrm{C}$, menunjukkan terjadi peningkatan denyut nadi dan suhu tubuh sebelum dan sesudah terpapar panas, denyut nadi rata-rata sebelum terpapar panas 65,50 denyut/menit dan rata-rata sesudah terpapar panas 80,83 denyut/menit, sedangkan ratarata suhu tubuh sebelum bekerja $36,9^{\circ} \mathrm{C}$ dan suhu sesudah bekerja $37,45^{\circ} \mathrm{C}$. (Imanuddin, 2012).

PT X merupakan perusahaan yang bergerak di bidang manufacturing yaitu perusahaan peleburan baja. Bahan baku utama yang diolah dalam peleburan adalah steel scrap dan sponge iron. Sedangkan bahan baku tambahannya adalah berupa ferro silicon, ferromanganese, ankerhart, ankerfrit, dolomite, lime, carbon raiser dan bahan penolong lainnya yang akan diolah menjadi billet dan wire rod/coil. Pengolahan dari bahan baku menjadi wire rod akan melalui beberapa proses produksi, salah satunya proses produksi yang dilakukan di Departemen Rolling Mill. Departemen Rolling Mill memiliki beberapa area kerja, salah satunya adalah $\mathrm{BRF}$ (billet re-heating form)

Dalam setiap prosesnya, tiap-tiap area kerja memiliki iklim kerja yang berbeda. Pada area BRF, dilakukan pemanasan ulang billet yang sudah dicetak pada proses sebelumnya. Tujuan dari pemanasan ulang ini adalah untuk memudahkan dalam pemrosesan kembali menjadi wire rod. Proses pemanasan ulang ini dilakukan dengan menggunakan mesin yang dioperasikan oleh operator dan diawasi langsung oleh beberapa pekerja yang berada di dekat mesin. Pada area BRF, iklim kerjanya cukup tinggi karena mesin yang digunakan mengeluarkan suhu panas. Adanya interaksi antara pekerja dan suhu panas tentunya memberikan efek pada pekerja. Pada area kerja ini salah satu 
hazard (bahaya) yang terasa adalah pajanan panas kepada pekerja.

Area kerja BRF di PT X melakukan pemanasan ulang billet yang sudah dicetak menjadi wire rod/ coil, dalam proses tersebut mesin pemanas (burner) mengeluarkan suhu yang cukup tinggi. Pekerja area tersebut terpapar panas dari mesin pemanas (burner) karena pekerja bekerja di bawah area burner untuk proses cleaning. Bahaya paparan panas yang terdapat pada kedua area kerja tersebut telah memajan pekerja dari waktu ke waktu sejak perusahaan ini memulai proses produksinya. Hal tersebut dapat meningkatkan suhu udara di lingkungan kerja, yang dapat berpengaruh langsung pada pekerja. Pengaruh akan peningkatan suhu udara di lingkungan dapat dilihat melalui keluhan-keluhan yang timbul dari setiap individu yang ada di area tersebut.

$$
\text { Kondisi panas yang berlebih }
$$

mengakibatkan rasa letih, kantuk, mengurangi konsentrasi dan meningkatkan angka kesalahan kerja yang sangat signifikan terjadi jika suhu udara melampaui $32^{\circ} \mathrm{C}$. Efek tekanan panas pada fisiologi tubuh adalah timbulnya heat strain (efek dari beban kerja fisik dan panas tubuh). Beberapa indeks yang digunakan untuk menentukan besarnya heat strain antara lain adalah banyaknya keringat yang dihasilkan, banyaknya keringat yang menguap, meningkatnya denyut nadi dan suhu tubuh. (Suma'mur, 2014).

Selain itu, panas dapat menyebabkan terjadinya dilatasi pembuluh darah perifer, sehingga keseimbangan peredaran darah akan terganggu. Dengan terjadinya keringat yang berlebihan, volume plasma berkurang sehingga volume darah juga berkurang, akibatnya tekanan darah turun dan pasokan $\mathrm{O}_{2}$ (oksigen) ke otak akan berkurang, dengan demikian orang akan kehilangan kesadarannya (Stam dalam Sari, 2014). Kondisi ini dapat mempengaruhi kondisi kesehatan pekerja dan menurunkan produktivitas kerja.

Berdasarkan uraian diatas, maka peneliti tertarik untuk melakukan penelitian untuk melihat peningkatan denyut nadi pada pekerja di area kerja BRF PT X, sehingga nantinya dapat dilakukan perbaikan dan pengendalian terhadap iklim kerja panas untuk mencapai produktivitas kerja yang tinggi pada pekerja.

Tujuan umum dari penelitian ini adalah untuk menganalisis hubungan antara tekanan panas dengan denyut nadi pada pekerja area BRF di PT X. Selain itu, terdapat tujuan khusus dalam penelitian, antara lain: mengukur dan mengidentifikasi tekanan panas pada area BRF di PT X, mengukur dan mengidentifikasi denyut nadi pekerja sebelumdan sesudah pekerja serta peningkatannya di area BRF di PT $X$, menilai beban kerja pekerja pada area BRF di PT X dan menganalisis hubungan tekanan panas dengan denyut nadi pekerja pada area kerja BRF di PT X.

\section{METODE PENELITIAN}

Penelitian ini merupakan jenis penelitian observasional analitik dengan pendekatan cross-sectional. Penelitian dilakukan pada bulan Februari - Juli 2016. Populasi penelitian adalah seluruh pekerja pada area kerja BRF di PT X sebanyak 25 orang pekerja. Sampel penelitian ini total sampling sebanyak 25 orang pekerja.

Metode pengumpulan data dalam penelitian ini terbagi dua, yaitu data primer meliputi tekanan panas, beban kerja dan denyut nadi pekerja. Data sekunder diperoleh dari data profil area kerja BRF di PT X.

Variabel penelitian terdiri dari 2 jenis, yaitu variabel dependen dan independen.Variabel dependen berupa denyut nadi dengan skala data rasio.Untuk variabel independen adalah tekanan panas (parameter ISBB) dengan skala data interval dan beban kerja dengan skala interval.

Metode pengukuran variabel tekanan panas dengan Digital QuesTemp, beban kerja dengan mengukur berat badan pekerja, mengamati aktivitas pekerja selama 4 jam bekerja dan menghitung kebutuhan kalori berdasarkan pengeluaran energi sesuai dengan tabel perhitungan beban kerja yang sudah ditetapkan oleh SNI7268-2009 dan pengukuran denyut nadi dilakukan dengan metode palpasi(raba) 
dengan bantuan alat pengukur waktu(stopwatch).

Pengumpulan data dilakukan dengan bantuan beberapa instrumen, yaitu:

a. Kuesioner karakteristik responden, status kesehatan dan kebiasaan responden;

b. Lembar penilaian beban kerja;

c. Lembar penilaian kondisi lingkungan kerja;

d. Timbangan berat badan;

e. Stopwatch;

f. Heat Stress Apparatus QUESTemp ${ }^{\circ \mathrm{TM}}$ 36.

Analisis data pada penelitian ini dilakukan secara univariat dan bivariat. Analisis univariat secara deskriptif yang menjelaskan distribusi frekuensi masingmasing variabel independen dan dependen pada penelitian ini. Analisis bivariat untuk menganalisis hubungan antara tekanan panas dengan peningkatan denyut nadi menggunakan uji korelasi Pearson dengan $\alpha=5 \%$ karena data berdistribusi normal dan memiliki skala data interval, rasio. Analisis kuat hubungan dikategorikan menjadi beberapa interval, sebagai berikut: (Sarwono, 2009)
a. 0 antara dua variabel
b. $0,00-0,25$ : Korelasi sangat lemah
c. $0,25-0,50$
d. $0,50-0,75$ kuat
: Korelasi cukup
e. $0,75-0,99$
: Korelasi kuat
f. 1
: Korelasi sangat
: Korelasi sempurna
Untuk korelasi negatif
interpretasi adalah sama.

\section{HASIL PENELITIAN DAN PEMBAHASAN}

Area kerja BRF di PT X adalah area kerja yang berada di dalam departemen Rolling Mill. Departemen Rolling Mill adalah departemen yang melakukan kegiatan produksi mengubah billet baja menjadi wire $\mathrm{rod} / \mathrm{coil}$.

Proses produksi di area kerja BRF, yaitu memanaskan billet baja dengan suhu 1215
${ }^{\circ} \mathrm{C}$ untuk memudahkan pembentukan dan mempercepat proses pembentukan menjadi wire $\mathrm{rod} / \mathrm{coil}$.

Pekerjaan di area kerja BRF PT X adalah pekerjaan cleaning yang dilakukan dibawah mesin pemanas billet. Dalam pekerjaan ini, pekerja membersihkan mill scale (residu dari pemanasan billet) yang menumpuk di bawah mesin pemanas billet untuk di kumpulkan dan dibawa ke tempat pembuangan limbah B3. Pekerjaan ini terdiri dari 4 macam aktivitas, antara lain: menyekop mill scale, mengangkat timba berisi mill scale $( \pm 25 \mathrm{~kg} / \mathrm{timba})$, mendorong kereta luncur yang berisi timba mill scale dan mengaitkan rantai dari timba berisi mill scale ke alat pengangkut (katrol).

Jam kerja di area kerja BRF di PT X dibagi dalam 3 shift. Pada penelitian ini, yang dijadikan sebagai responden penelitian adalah pekerja area BRF yang bekerja pada shift I. Jam kerjanya dimulai pada pukul 07.00 WIB dan berakhir pada pukul 15.00 WIB. Diantara jam tersebut terdapat waktu istirahat yang telah diatur oleh manajemen dan berlaku untuk semua pekerja pada shift I, yaitu pada pukul 12.00 WIB sampai 13.00 WIB.

Responden penelitian adalah pekerja dari area BRF dan TFH di PT X sebanyak 25 orang dan semua berjenis kelamin laki-laki.Pada tabel 1. didapatkan distribusi karakteristik responden berdasarkan usia dan masa kerja. Sebagian besar responden yang bekerja padaarea kerja BRF PT X berusia kurang dari sama dengan 40 tahun atau sebesar 56\% sedangkan sebesar $44 \%$ berusia $>40$ tahun.Untuk masa kerja didapatkan distribusi karakteristik responden cukup beragam dengan masa kerja paling pendek adalah 3 tahun dan yang paling panjang/lama adalah 15 tahun.Tabel 1.Menunjukkanbahwa masa kerja 14 responden pada area BRF di PT X adalah selama $\leq 9$ Tahun atau sebesar $56 \%$ dan sisanya bekerja selama $>9$ Tahun. Usia pekerja yang memiliki masa kerja $\leq 9$ tahun kebanyakan $<40$ tahun. 
Tabel 1. Distribusi Karakteristik Respondenpada Area Kerja BRF di PT X Tahun 2016

\begin{tabular}{|c|c|c|c|}
\hline \multirow{2}{*}{ No } & \multirow{2}{*}{ Karakteristik Responden } & \multicolumn{2}{|c|}{ Area kerja BRF } \\
\hline & & $n$ & $\%$ \\
\hline 1 & $\begin{array}{l}\text { Usia: } \\
>40 \text { Tahun } \\
\leq 40 \text { Tahun }\end{array}$ & $\begin{array}{l}11 \\
14\end{array}$ & $\begin{array}{l}44 \\
56\end{array}$ \\
\hline 2 & $\begin{array}{l}\text { Masa Kerja: } \\
>9 \text { Tahun } \\
\leq 9 \text { Tahun }\end{array}$ & $\begin{array}{l}11 \\
14\end{array}$ & $\begin{array}{l}44 \\
56\end{array}$ \\
\hline & Jumlah & 25 & 100 \\
\hline
\end{tabular}

Indeks Suhu Bola Basah (ISBB) merupakan salah satu indikator yang digunakan untuk mengukur tekanan panas. Pengukuran ISBB dilakukan sebanyak 3 (tiga) kali pada titik yang telah ditentukan, yaitu titik A dan titik B. Tabel 2. menunjukkan bahwa ISBB pada area kerja BRF di PT X mengalami peningkatan di kedua titik lokasi, selama 4 (jam)dilakukan pengukuran dengan rerata pengukuran suhu tertinggi terdapat pada titik A, yaitu sebesar $34,6^{\circ} \mathrm{C}$.

Tabel 2.Hasil Pengukuran ISBB pada Area Kerja BRF di PT XTahun2016

\begin{tabular}{|c|c|c|c|c|}
\hline \multirow{2}{*}{$\begin{array}{c}\text { Lokasi } \\
(\mathrm{BRF})\end{array}$} & \multicolumn{3}{|c|}{ Pengukuran ISBB } & \multirow{2}{*}{$\begin{array}{c}\text { Rerata } \\
\left({ }^{\circ} \mathrm{C}\right)\end{array}$} \\
\cline { 2 - 4 } & $\mathrm{I}$ & $\mathrm{II}$ & $\mathrm{III}$ & \\
\hline Titik A & 33,5 & 34,6 & 35,7 & 34,6 \\
\hline Titik B & 33,5 & 34,4 & 35,8 & 34,5 \\
\hline
\end{tabular}

Beban kerja responden dinilai dengan menggunakan metode penilaian beban kerja berdasarkan tingkat kebutuhan kalori menurut pengeluaran energi yang terdapat pada SNI 7268-2009.Prinsip penilaian beban kerja dilakukan dengan mengukur berat badan pekerja, mengamati aktivitas pekerja dan menghitung kebutuhan kalori berdasarkan pengeluaran energi sesuai dengan tabel perhitungan beban kerja yang sudah ditetapkan oleh SNI.

untuk $\begin{array}{crr}\text { Penilaian beban kerja dilakukan } \\ \text { melihat }\end{array}$
respondentermasuk kedalam kategori beban kerja ringan, sedang atau berat. Dari hasil penilaian, seluruh beban kerja responden area kerja BRF di PT $X$ rata-rata membutuhkan kalori sebesar 485,65 $\mathrm{Kkal} / \mathrm{jam}$ untuk bekerja, dan jika dilihat kebutuhan kalori seluruh responden tersebut berada pada range antara $>350$
$\mathrm{Kkal} /$ jam hingga $\leq 500 \mathrm{Kkal} / \mathrm{jam}$, sehingga beban kerja seluruh responden area kerja BRF di PT X dapatdikategorikankedalam beban kerja berat.

Pengukuran denyut nadi dilakukan sebanyak 2 kali, yaitu sebelum responden bekerja (sebelum terpapar panas) dan sesudah responden bekerja (sesudah terpapar panas) menggunakan metode palpasi (raba) dengan rentang waktu 1 menit pengukuran.Berikut adalah hasil pengukuran denyut nadi responden sebelum dan sesudah 4 jam terpapar panas pada area kerja BRF dan TFH di PT X.

Tabel 3. menunjukkan bahwa rerata pengukuran denyut nadi pada area kerja BRF di PT X sebelum bekerja adalah 70 denyut/menit dengan denyut nadi terendah sebesar 60 denyut/menit dan denyut nadi tertinggi sebesar 79 denyut/menit. Rerata pengukuran denyut nadi pada area kerja BRF di PT X sesudah bekerja adalah 107 denyut/menit dengan denyut nadi terendah sebesar 60 denyut/menit dan denyut nadi tertinggi sebesar 123 denyut/menit.

Hasil penelitian diketahui bahwa peningkatan denyut nadi pekerja pada area kerja BRF di PT $\mathrm{X}$ dengan ISBB diatas NAB dan beban kerja kategori berat memiliki rerata sebesar 38 denyut/menit dan sebanyak 22 responden (88\%) mengalami peningkatan denyut nadi.Tidak adanya peningkatan denyut nadi terhadap 3 orang responden di pengaruhi oleh kebiasaan minum pekerja dan masa kerja sehingga, sehingga pekerja tidak mengalami respon fisiologis yang tampak karena pekerja sudah tercukupi cairan tubuhnya dan sudah beraklimatisasi dengan sangat baik. 
Tabel 3.Hasil Pengukuran Denyut Nadi Responden pada Area kerja BRF di PT X Tahun 2016

\begin{tabular}{|c|c|c|c|c|}
\hline \multirow[b]{2}{*}{ No. Responden } & \multicolumn{2}{|c|}{ Denyut Nadi (denyut/menit) } & \multirow[b]{2}{*}{$\begin{array}{l}\text { Peningkatan Denyut Nadi } \\
\text { (denyut/menit) }\end{array}$} & \multirow[b]{2}{*}{$\begin{array}{l}\text { Keterangan } \\
\text { Denyut nadi }\end{array}$} \\
\hline & $\begin{array}{c}\text { Sebelum } \\
\text { Bekerja }\end{array}$ & $\begin{array}{l}\text { Sesudah } \\
\text { Bekerja }\end{array}$ & & \\
\hline 1 & 76 & 110 & 34 & Meningkat \\
\hline 2 & 69 & 123 & 54 & Meningkat \\
\hline 3 & 64 & 105 & 41 & Meningkat \\
\hline 4 & 72 & 93 & 21 & Meningkat \\
\hline 5 & 79 & 110 & 31 & Meningkat \\
\hline 6 & 60 & 104 & 44 & Meningkat \\
\hline 7 & 72 & 102 & 30 & Meningkat \\
\hline 8 & 64 & 114 & 50 & Meningkat \\
\hline 9 & 67 & 108 & 41 & Meningkat \\
\hline 10 & 71 & 117 & 46 & Meningkat \\
\hline 11 & 73 & 120 & 47 & Meningkat \\
\hline 12 & 68 & 101 & 33 & Meningkat \\
\hline 13 & 76 & 122 & 46 & Meningkat \\
\hline 14 & 66 & 97 & 31 & Meningkat \\
\hline 15 & 74 & 100 & 26 & Meningkat \\
\hline 16 & 72 & 111 & 39 & Meningkat \\
\hline 17 & 76 & 106 & 30 & Meningkat \\
\hline 18 & 62 & 98 & 36 & Meningkat \\
\hline 19 & 63 & 105 & 42 & Meningkat \\
\hline 20 & 66 & 99 & 33 & Meningkat \\
\hline 21 & 60 & 60 & - & Tetap \\
\hline 22 & 62 & 62 & - & Tetap \\
\hline 23 & 66 & 89 & 8 & Meningkat \\
\hline 24 & 65 & 93 & 7 & Meningkat \\
\hline 25 & 61 & 61 & - & Tetap \\
\hline
\end{tabular}

Pengukuran tekanan panas merupakan hasil observasi yang tidak memiliki variasi dalam datanya, artinya setiap pekerja terpapar oleh tekanan panas yang samapada area kerja tersebut, yang membedakan adalah beban kerja yang diterima oleh fisik akibat dari aktivitas yang dilakukan pada saat mereka bekerja.

Pengujian hubungan dilakukan dengan menggunakan Uji Korelasi Pearson karena setelah dilakukan uji normalitas data diatas, didapatkan hasil bahwa data berdistribusi normal. Pengujian dilakukan dengan hipotesis sebagai berikut:
$H_{0:}$ Tidak ada hubungan antara paparan panas dengan peningkatan denyut nadi pekerja pada area kerja BRF di PT X.

$H_{l}$ : Ada hubungan antara paparan panas dengan peningkatan denyut nadi pekerja pada area kerja

BRF di PT X.

Tabel 4. Korelasi Paparan Panas dengan Peningkatan Denyut Nadi pada Area Kerja BRF di PT X Tahun 2016

\begin{tabular}{|c|c|c|}
\hline Area Kerja & $\begin{array}{c}r \text { (nilai koefisien } \\
\text { korelasi) }\end{array}$ & $p$-value \\
\hline BRF & 0,507 & 0,022 \\
\hline
\end{tabular}


Berdasarkan hasil pengujian pada area kerja BRF di PT X, diperoleh nilai $p$ value $=0,022$ dengan $\alpha$ sebesar 5\%, maka diperoleh keputusan $H_{0}$ ditolak karena nilai $p$-value $<\quad \alpha \quad(0,05)$ sehingga dapat disimpulkan bahwa ada hubungan antara paparan panas dengan peningkatan denyut nadi pekerja pada area kerja BRF di PT X.

Kuat hubungan dari kedua variabel dapat dilihat melalui nilai $r$ (koefisien korelasi). Area kerja BRF memiliki nilai $r$ sebesar 0,507 yang menunjukkan bahwa interval kekuatan hubungan berada pada rentang 0,50-0,75 yang berarti kedua variabel memiliki korelasi kuat atau hubungan yang kuat. Arah hubungan antar kedua variabell positif $(+)$ dilihat dari nilai $r$, maka semakin tinggi paparan panas ditempat kerja, semakin tinggi peningkatan denyut nadi yang dialami oleh pekerja pada area BRF di PT X.

\section{PEMBAHASAN}

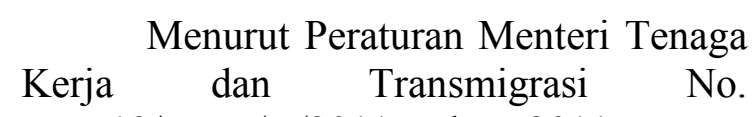
PER.13/MEN/X/2011 Tahun 2011 tentang Nilai Ambang Batas Faktor Fisika dan Faktor Kimia di Tempat Kerja,NAB ISBB di area kerja BRF dengan pengaturan waktu kerja setiap jam sebesar 75\%-100\% dengan kategori beban kerja berat adalah pekerja tidak diperkenankan untuk terpapar panas diluar suhu nyaman untuk bekerja. Hasil pengukuran ISBB pada area kerja BRF di titik A dan titik $\mathrm{B}$ menunjukkan bahwa paparan panas di area kerja tersebut telah melebihi NAB, yaitu sebesar $34,6{ }^{\circ} \mathrm{C}$ dititik $\mathrm{A}$ dan $34,5{ }^{\circ} \mathrm{C}$ di titik $\mathrm{B}$. ISBB yang melebihi $\mathrm{NAB}$ di area kerja BRFselain disebabkan oleh tingginya iklim kerja panas di lingkungan kerja juga disebabkan oleh beratnya aktivitas fisik yang di lakukan pekerja(Nurmianto, 1996).Iklim kerja yang telah melampaui suhu $32^{\circ} \mathrm{Cmemiliki}$ dampak dapat mengurangi kelincahan, mengganggu koordinasi saraf motoris dan memudahkan emosi untuk di rangsang (Suma'mur, 2014).Hal ini sesuai dengan hasil wawancara singkat dengan beberapa pekerja, bahwa mereka sering merasa mudah emosi dan cepat lelah saat bekerja di iklim kerja panas yang disertai dengan beban kerja yang berat.Beratnya aktivitas fisik dapat berubah menjadi beban kerja fisik saat pekerja melakukan aktivitas pekerjaan yang melebihi kapasitas fisiknya (Rodahl dalam Wibowo, 2012).Pekerja area BRF melakukan aktivitas fisik diluar kapasitasnya sehingga dalam penilaian beban kerja seluruh pekerja masuk ke dalam kategori beban kerja berat.

Penilaian beban kerja pada area kerja BRF dengan jumlah responden sebanyak 25 orang didapatkan hasil bahwa beban kerja seluruh responden (100\%) masuk ke dalam kategori beban kerja berat dengan kebutuhan kalori yang berada pada range antara $>350 \mathrm{Kkal} /$ jam hingga $\leq 500$ Kkal/jam. Pekerja melakukan serangkaian aktivitas yang membutuhkan kekuatan fisik dalam pelaksanaanya, antara lain menyekop mill scale, mendorong kereta luncur berisi mill scale, dan mengangkuttimba mill scale seberat $\pm 25 \mathrm{~kg}$ secara repetitive (berulang kali).Berdasarkan hasil observasi dan wawancara terhadap pekerja area BRF, PT $\mathrm{X}$ sudah membantu mengurangi beban kerja dengan pemilihan alat kerja yang sesuai, yaitu dengan penggunaan kereta luncur untuk membawa timba berisi mill scale. Namun, hal lain yang tidak diperhatikan oleh PT $\mathrm{X}$ adalah pekerja tetap harus mengangkut timba berisi mill scale untuk dinaikkan ke atas kereta luncur. Meskipun berat beban yang di angkut dibawah dari batas rekomendasi maksimum, namun jika hal itu dilakukan secara repetitive selama 8 jam kerja/hari akan membahayakan kondisi kesehatan pekerja dan dapat mempengaruhi respon fisiologisnya.Menurut Suma'mur (2014) agar seorang pekerja berada dalam keserasian sebaik-baiknya, yang berarti bahwa pekerja tersebut dapat terjamin keadaan kesehatan dan produktivitas kerjanya secara optimal, maka perlu adanya keseimbangan antara beban kerja yang diterima dengan kapasitas kerjanya.Setiap pekerja memiliki kemampuan tersendiri dalam hal kapasitas menanggung beban kerjanya, hingga mencapai pembebanan kerja yang paling optimal.Menurut rekomendasi ILO untuk pekerjaan mengangkut barang dengan ukuran tubuh dan otot orang Indonesia, batas maksimum 
beban yang diperkenankan adalahsebesar $35 \mathrm{~kg}$.Lebih dari itu dapat membahayakan kondisi kesehatan pekerja.

Peningkatan denyut nadi merupakan salah satu respon fisiologis yang dialami oleh pekerja terhadap kombinasi antara paparan panas dan tingginya tingkat beban kerja yang diterima.Tinggi rendahnya peningkatan denyut nadi tergantung dari kapan pengukuran denyut nadi sesudah bekerja dilakukan.Pengukuran denyut nadi sesudah bekerja paling baik dilakukan sesaat setelah pekerja melakukan pekerjaannya (sesaat pekerja terpapar panas) karena dampak dari kombinasi paparan panas yang didapat dari lingkungan kerja dan beban kerja dapat langsung terlihat melalui peningkatan denyut nadi tersebut. Jika pengukuran dilakukan 5 menit setelah bekerja, maka hasilnya akan sama dengan pengukuran sebelum bekerja karena denyut nadi sudah pulih kembali dan tidak dapat dilihat peningkatannya. Hasil penelitian diketahui bahwa peningkatan denyut nadi pekerja pada area kerja BRF di PT $X$ dengan ISBB diatas NAB dan beban kerja kategori berat memiliki rerata sebesar 38 denyut/menit dan seluruh responden $(100 \%)$ mengalami peningkatan denyut nadi. Hal ini sesuai dengan Moeljosoedarma (2008) yang mengatakan bahwa peningkatan denyut nadi pekerja yang terpapar panas tinggi dengan beban kerja yang tinggi berkisar antara 20-40 denyut/menit. Hal ini serupa dengan penelitian yang dilakukan oleh Aperos, et al (2015) sebanyak 58\% responden mengalami kenaikan denyut 20-30 denyut/menit dengan paparan panas yang tinggi dan beban kerja kategori berat.

Hasil dari uji statistik Korelasi Pearsondi area kerja BRF, di dapatkan hasil bahwa ada hubungan yang kuat antara paparan panas dengan peningkatan denyut nadi pekerja pada area kerja BRF di PT X. Hubungan antara kedua variabel memiliki arah hubungan positif $(+)$ yang berarti semakin tinggi paparan panas ditempat kerja, semakin tinggi peningkatan denyut nadi yang dialami oleh pekerja pada area BRF di PT X.Hal ini sesuai dengan hasil penelitian yang telah dilakukan. Area BRF yang memiliki ISBB diatas NAB dengan beban kerja kategori berat, rerata peningkatan denyut sebesar 38 denyut/menit.Hal tersebut membuktikan bahwa hubungan antara tekanan panas dengan denyut nadi berbanding lurus. Semakin tinggi tekanan panas di suatu lingkungan kerja maka denyut nadi juga akan semakin meningkat sehingga menunjukkan kecenderungan suatu hubungan yang positif $(+)$.Hal ini sejalan dengan pernyataan Santoso (2005) yang menyatakan bahwa tekanan panas yang berlebihan akan menjadi beban tambahan yang harus diperhatikan dan diperhitungkan. Beban tambahan berupa panas lingkungan dapat menyebabkan beban fisioologis misalnya kerja jantung menajdi bertambah. Studi lain dari Istiary (2012) dan Agustin (2014) juga mengungkapkan bahwa terdapat peningkatan denyut nadi pada pekerja yang terpapar panas. Peningkatan tersebut terjadi karenanilai ISBB melebihi NAB yang diperkenankan, sehingga muncul respon fisiologis dari pekerja, berupa peningkatan denyut nadi.Pemaparan panas dapat menyebabkan beban tambahan pada sirkulasi darah, maka darah akan mendapat beban tambahan tersebut, karena harus membawa oksigen ke bagian otot yang sedang bekerja. Pada waktu melakukan pekerjaan fisik yang berat di lingkungan panas, maka darah akan mendapat beban tambahan karena harus membawa oksigen kebagian otot yang sedang bekerja dan membawa panas dari dalam tubuh ke permukaan kulit sehingga menjadi beban tambahan bagi jantung yang harus memompa darah lebih banyak lagi yang mengakibatkan frekuensi denyut nadipun menjadi lebih lebih cepat (Santoso, 2005).

\section{SIMPULAN}

Hasil penelitian terhadap 25 orang pekerja yang menjadi sampel penelitian hubungan tekanan panas dengan denyut nadi pekerja pada area kerja BRF di PT X, diperoleh bahwa:

1. Paparan panas dengan peningkatan denyut nadi pekerja area BRF di PT X memiliki hubungan yang positif, yang 
artinya semakin tinggi paparan panas yang ada ditempat kerja semakin tinggi pula peningkatan denyut nadi pekerja.

2. Beban kerja juga memiliki hubungan kuat terhadap peningkatan denyut nadi pekerja pada area kerja BRF dengan nilai $r=0,507$. Hubungan yang terjadi adalah hubungan positif.

\section{DAFTAR PUSTAKA}

Aperos, M.I, Tarigan, L., and Sinaga, M.M., 2015. Hubungan Tekanan Panas dengan Denyut Nadi pada Pekerja di PT Pekerbunan Nusantara Kebun Bah Butong tahun 2015, Jurnal USU, [ejournal] 8(28): pp.1-8. Tersedia di $<$ http:/jurnal.usu.ac.id/index.php/1 kk/article/download/11469/5784> [diakses tanggal 20 Juli 2016].

Imanuddin, A., 2012. Hubungan

Karakteristik Pekerja dengan

Keluhan Subyektif Saluran

Pernafasan Akibat Paparan Debu

Kapas dan Upaya

Pengoendaliannya di Bagian

Zenbo Spinning PT. Mertex

Industry Indonesia. Skripsi.

Surabaya. Universitas Airlangga.

Moeljosoedarma, Soeripto., 2008. Higiene

Industri. Jakarta: FK Universitas Indonesia.

Nurmianto, E., 1996. Ergonomi, Konsep

Dasar dan Aplikasinya, Surabaya:

PT. Guna Widya.

Santoso, G. 2004., Higiene Perusahaan

Panas. Solo: Fakultas Kedokteran

Universitas Sebelas Maret.

Sari, N.P., 2014. Pengaruh Iklim Kerja

Panas terhadap Dehidrasi dan

Kelelahan pada Tenaga Kerja bagian Boiler di PT. Albasia Sejahtera Mandiri, Kabupaten Semarang. Skripsi. Surakarta. Universitas Muhammadiyah Surakarta.

Sarwono. J, 2009. Statistik Itu Mudah:

Panduan Lengkap untuk Belajar

Komputasi Statistik

Menggunakan SPSS 16.

Yogyakarta: Universitas Atma

Jaya Yogyakarta
Siswantiningsih, K.A., 2010. Perbedaan Denyut Nadi Sebelum dan Sesudah Bekerja pada Iklim Kerja Panas di Unit Workshop PT. Indo Acidatama Tbk. Kemiri, Tugas Akhir. Surakarta.

Suma'mur P.K. 2014., Higiene Perusahaan dan Kesehatan Kerja (Hiperkes). Jakarta: PT. Sagung Seto.

Undang-Undang Republik Indonesia No. 1 tahun 1970 tentang Keselamatan dan Kesehatan Kerja.

Vanani, N.S. 2010., Gambaran Tekanan Panas dan Keluhan Subyektif pada Pekerja di Bagian Curing PT. Multistrada Sarana, Tbk. Skripsi. Depok.

Wibowo, A.B. 2012. Dampak beban Kerja terhadap Stress Kerja pada Perawat RSUD Prof. Dr. Seokandar Mojokerto. Skripsi 